\title{
PP4 deficiency leads to DNA replication stress that impairs immunoglobulin class switch efficiency
}

\author{
Ming-Yu Chen ${ }^{1}$ - Wei-Chan Hsu ${ }^{1}$ Shu-Ching Hsu ${ }^{2,3,4} \cdot$ Yu-Shao Yang ${ }^{2} \cdot$ Tsung-Hsien Chuang ${ }^{1} \cdot$ Wen-Jye Lin ${ }^{1}$. \\ Tse-Hua Tan $\mathbb{D D}^{1,5} \cdot$ Yu-Wen Su${ }^{1}$
}

Received: 20 February 2018 / Revised: 30 July 2018 / Accepted: 27 August 2018 / Published online: 20 September 2018

(c) The Author(s) 2018. This article is published with open access

\begin{abstract}
The serine/threonine phosphatase PP4 has been implicated in DNA damage repair and cell cycle regulation through its dephosphorylation of specific substrates. We previously showed that PP4 is required for mouse B cell development, germinal center (GC) formation and immunoglobulin (Ig) class switch recombination (CSR). Here, we investigate the mechanisms underlying this requirement and demonstrate that murine PP4-deficient B lymphocytes have a defect in cell proliferation. Strikingly, the DNA damage response pathway that involves ATM/p53 and is linked to cell cycle arrest and impaired cell survival is strongly induced in these mutant B cells. In response to LPS + IL-4, stimuli that trigger IgG1 production, these PP4-deficient B cells show inefficient phosphorylation of ATR, leading to reduced retention of $\gamma \mathrm{H} 2 \mathrm{AX}-\mathrm{NBS} 1$ complexes at sites of DNA damage, and compromised switching to IgG1. However, beyond the cell proliferation phase, conditional deletion of PP4 under the control of AID/cre completely restores normal IgG1 production in mutant B cell cultures. In vivo, co-deletion of PP4 and p53 by AID/cre partially rescues switching to IgG1 in B cells of mice immunized with TNP-KLH. Our findings establish that PP4 is indispensable for preventing DNA replication stress that could interfere with CSR, thereby promoting antibody switching during the humoral immune response.
\end{abstract}

\section{Introduction}

In response to antigen challenge, naïve $\mathrm{B}$ cells become activated, proliferate and form a germinal center (GC),

Edited by T. Mak

Electronic supplementary material The online version of this article (https://doi.org/10.1038/s41418-018-0199-z) contains supplementary material, which is available to authorized users.

Yu-Wen Su

yuwensu@nhri.org.tw

1 Immunology Research Center, National Health Research Institutes (NHRI), Zhunan, Miaoli County, Taiwan

2 National Institute of Infectious Diseases and Vaccinology, NHRI, Zhunan, Miaoli County, Taiwan

3 Graduate Institute of Medicine, College of Medicine, Kaohsiung Medical University, Kaohsiung, Taiwan

4 Department of Medical Research and Development, Chang Bing Show Chwan Memorial Hospital, Chang Hua, Taiwan

5 Department of Pathology \& Immunology, Baylor College of Medicine, Houston, TX, USA which is essential for the induction of an adaptive humoral immune response. During GC formation, B cells with surface expression of immunoglobulin (Ig) of subclass IgM undergo class switch recombination (CSR), in which the gene segment encoding the Ig constant (C) $\mu$ region is excised from the DNA and replaced with one of the available 3 ' Ig constant regions $\mathrm{C} \gamma, \mathrm{C} \varepsilon$, or $\mathrm{C} \alpha$. This process is catalyzed by activation-induced cytidine deaminase (AID) via conversion of cytosines to uracils in the $\mathrm{S}$ regions located upstream of each of the $\mathrm{C}$ regions [1]. The uracil bases are subsequently processed by uracil DNA glycosylase (UNG) and apurinic/apyrimidinic endonuclease (APE), resulting in DNA double-strand breaks (DSBs) at the donor and the acceptor $\mathrm{S}$ regions [2]. The presence of DSBs in DNA activates ATM kinase to phosphorylate p53 and other substrates, resulting in cell cycle regulation and/or apoptosis [3]. During DNA DSB formation, H2AX is immediately activated and phosphorylated at S139 by ATM or ATR to form phosphorylated $\mathrm{H} 2 \mathrm{AX}$ (also called $\gamma \mathrm{H} 2 \mathrm{AX}$ ). $\gamma \mathrm{H} 2 \mathrm{AX}$ subsequently recruits DNA damage molecules such as the MRN complex, composed of Mre11, Rad50, and NBS1, which recruits and activates ATR for DNA repair [4-8]. During DNA damage and DNA replication, replication 
protein A (RPA) complex consisting of RPA1, RPA2, and RPA3 is recruited to single-stranded lesions in DNA, that stabilizes stalled replication fork and facilitates the activation of ATR signaling [9, 10]. To complete CSR, the broken $\mathrm{S}$ regions in the Ig loci are re-joined by the homologous recombination (HR) pathway or the classical nonhomologous end-joining (NHEJ) pathway [11]. During such DNA repair, $\gamma \mathrm{H} 2 \mathrm{AX}$ functions synergistically with NBS1 [12, 13] to maintain genomic stability [14-16]. In addition, both $\gamma \mathrm{H} 2 \mathrm{AX}$ and NBS1 are required to complete Ig class switching [17-19]. Once CSR is successful, the B cells produce IgG, IgE, or IgA antibodies whose effector functions confer comprehensive immune protection [20].

Protein phosphatase 4 (PP4) is a well-conserved holoenzyme composed of a catalytic subunit termed PP4c and multiple regulatory subunits. Through its dephosphorylation of various substrates, PP4 has been implicated in microtubule organization [21, 22], histone modification [23], and signal transduction [24-28]. Furthermore, PP4 plays essential roles in DNA damage responses and DNA repair by dephosphorylating DBC1 [29] and KAP1 [30-32], and regulates cell cycle progression by dephosphorylating $\gamma \mathrm{H} 2 \mathrm{AX}$ and RPA2 [33-36]. Lastly, several lines of evidence support a crucial function for PP4 in cell proliferation [37-40].

We have previously shown using B cell-specific PP4deficient mice that $\mathrm{B}$ cell development and GC formation are impaired in the absence of this phosphatase and that CSR efficiency is reduced [41, 42]. However, due to the multiple physiological roles of PP4 within mammalian cells, the precise molecular mechanism regulated by PP4 during CSR was unclear. In this study, we utilized CD23/cre or AID/cre to delete the PP4 gene conditionally in mature mouse B cells or activated GC B cells, respectively, to study the effect of PP4 deficiency specifically on CSR. We found that, in response to treatment with lipopolysaccharide plus interleukin-4 (LPS + IL-4), B cells in which PP4 was deleted under the control of CD23/cre underwent cell cycle arrest in $\mathrm{S}$ phase. These mutant B cells suffered severe DNA damage as revealed by their vigorous activation of the ATM-p53 pathway. In the early phase in response to LPS + IL-4, ATR was not efficiently phosphorylated in these B cells and fewer $\gamma \mathrm{H} 2 \mathrm{AX}-\mathrm{NBS} 1$ complexes were retained at sites of DNA damage. In contrast, deletion of PP4 by AID/cre completely rescued B cell proliferation and restored normal levels of switching to IgG1 in vitro. Co-deletion of PP4 and p53 by AID/cre led to a partial rescue of $\mathrm{IgG1}^{+} \mathrm{B}$ cells in vivo in mice immunized with TNR-KLH. Our findings reveal that PP4 is crucial for CSR due to its function in preventing DNA replication stress.

\section{Materials and Methods}

\section{Mice}

$\mathrm{PP} 4^{\mathrm{F} / \mathrm{F}}$ mice [24], CD23/cre mice [43], AID/cre mice [43], and $\mathrm{p} 53^{\mathrm{F} / \mathrm{F}}$ mice (Jackson lab Stock 008462) [44] generated as previously described were maintained in the Laboratory Animal Center of the National Health Research Institute (NHRI). The CD23/cre mice and AID/cre mice used in all experiments were heterozygous. Double mutant mice were generated in-house using standard breeding procedures. Age-matched mice (8-12 weeks old) were used in all experiments. All mice were euthanized by carbon dioxide inhalation. The mouse numbers for each experiment are specified in the Figure Legends. All animal studies were reviewed and approved by NHRI's Institutional Animal Care and Use Committee (Permit Number: 099111-A, 103075-A, and 105033-A), and all efforts were made to minimize mouse suffering.

\section{B cell purification and cell culture}

Single cell suspensions were prepared as described previously [42]. In brief, non-B cells were depleted using a cocktail of biotin-conjugated Abs recognizing NK1.1, Thy1.2, Gr1, CD11b, CD11c, or Ter119 (BD Biosciences), followed by application of $\mathrm{IMag}^{\mathrm{TM}}$ Streptavidin Particles Plus beads (BD Biosciences). B cells of purity between 96-98\% were cultured in RPMI 1640 medium supplemented with $2 \mathrm{mM}$ L-glutamine (Gibco), $100 \mathrm{U} / \mathrm{ml}$ penicillin plus $100 \mu \mathrm{g} / \mathrm{ml}$ streptomycin (Gibco), $10 \mathrm{mM}$ Hepes (Gibco), $1 \mathrm{mM}$ sodium pyruvate (Gibco), $0.055 \mathrm{mM}$ 2-mercaptoethanol (Gibco), and 10\% FBS (Hyclone) (maintenance medium).

\section{Proliferation assays}

For CFSE decay or VPD experiments, B cells were seeded at a density of $2 \times 10^{7}$ in $1 \mathrm{ml}$ PBS and incubated with $5 \mu \mathrm{M}$ carboxyfluorescein succinimidyl ester (CFSE, Sigma) or $1 \mu \mathrm{M}$ Violet Proliferation Dye 450 VPD450 (BD Horizon ${ }^{\mathrm{TM}}$ ) at room temperature (RT) for $10 \mathrm{~min}$ with gentle mixing. To stop labeling, $10 \mathrm{ml}$ $10 \%$ maintenance medium was added to cells followed by centrifugation at $1500 \mathrm{rpm}$ for $10 \mathrm{~min}$. Cell pellets were suspended in PBS or maintenance medium and used for experiments. For BrdU incorporation, B cells were seeded at a density of $1 \times 10^{6} / \mathrm{ml}$ (without stimulation), cultured in maintenance medium containing $10 \mu \mathrm{M}$ BrdU (Sigma) for $72 \mathrm{~h}$, and analyzed using the BrdU Flow Kit (BD Pharmingen ${ }^{\mathrm{TM}}$ 552598) following the manufacturer's instructions. 


\section{Induction of CSR}

B cells were seeded at a density of $1 \times 10^{6} / \mathrm{ml}$ and cultured for 1 to 6 days in maintenance medium containing either $10 \mu \mathrm{g} / \mathrm{ml}$ LPS (InVivo Gene) to induce switching to IgG3, or in maintenance medium containing $10 \mu \mathrm{g} / \mathrm{ml}$ LPS plus $20 \mathrm{ng} / \mathrm{ml} \mathrm{IL}-4$ (PeproTech) to induce switching to IgG1. B cells with surface expression of IgG1 or IgG3 were identified by flow cytometric analysis of the $\operatorname{IgM}^{-} \operatorname{IgD}^{-}$gated population as described below.

\section{Flow cytometric analyses (FACS)}

Single cell suspensions of $1 \times 10^{6}$ cells were washed twice with FACS buffer (2\% BSA/PBS, $\left.0.01 \% \quad \mathrm{NaN}_{3}\right)$ and maintained in the dark at $4{ }^{\circ} \mathrm{C}$ throughout experiments. Flow cytometric data were acquired using a CantoII flow cytometer and FACSDiva software (both from BD Biosciences). FlowJo software (Tree Star, Inc.) was used for data analyses. For marker expression determinations, cells were incubated for $15 \mathrm{~min}$ on ice with anti-mouse antibodies recognizing IgG1 (RMG1-1)-FITC/BV510, CD138 (281-2)-PE (all from eBioscience), B220 (RA3-6B2)-APC/ APC-Cy7, IgD (11-26 c.2a)-FITC/PE/Pacific blue/BV510, IgM (II/41)-FITC/APC/PE-Cy7, IgG3 (R40-82)-biotin, or streptavidin-APC (all from BD Biosciences).

For viability determinations, immunostained cells were washed twice in FACS buffer prior to incubation with 7AAD (Sigma). Viable cells were gated from the 7AADnegative population prior to analysis. For intracellular staining, cells were fixed and permeabilized using the Fixation/Permeabilization solution kit (BD, Cat. NO. 554714) following the manufacturer's instructions, and stained with anti-p-ATM S1981-PE (10H11.E12, Millipore).

\section{Immune response in vivo}

To examine immune responses and class switching in vivo, mice were i.p. immunized with $5 \mu \mathrm{g} / \mathrm{g}$ body weight of the Tdependent antigen TNP-Keyhole Limpet Hemocyanin (TNP-KLH, BIOSEARCH) suspended in alum (Sigma). Spleen samples were harvested on day 0 and day 14 postimmunization, and IgG1 switching was analyzed by flow cytometry as described above.

\section{Retroviral transduction}

Retroviral vector pMSCV-PIG (Puro-IRES-GFP) empty vector [45] was a gift from David Bartel (Addgene plasmid \# 21654). To express genes of interest by retroviral system, genes encoding PP4 WT, PP4 R236L, p53 WT, p53 S15A, or p21 were cloned into the multiple cloning sites of
pMSCV-PIG. Retroviral vectors were transfected into Phoenix cells using calcium phosphate, and supernatants containing virus particles were harvested after $48 \mathrm{~h}$. Prior to transduction, purified B cells were seeded at $1 \times 10^{6} / \mathrm{ml}$ in 24-well plates in maintenance medium containing $10 \mu \mathrm{g} / \mathrm{ml}$ LPS plus $20 \mathrm{ng} / \mathrm{ml} \mathrm{IL}-4$ and incubated for $24 \mathrm{~h}$. To infect stimulated B cells, the culture medium was replaced by $750 \mu \mathrm{l}$ viral supernatant containing $8 \mu \mathrm{g} / \mathrm{ml}$ protamine sulfate (Sigma), and cells were centrifuged at $2500 \mathrm{rpm}$ for $90 \mathrm{~min}$. Transduced cells were cultured for another $48 \mathrm{~h}$ in maintenance medium before evaluation of GFP and IgG1 expression by FACS analysis.

\section{RT-PCR}

To examine levels of germline and class-switched Ig transcripts, PCR oligomer primers and reaction conditions were employed as previously reported [46]. PCR reactions were performed using mRNA extracted from $B$ cells that had been left unstimulated, or stimulated with LPS alone, or with LPS + IL- 4 for 1 to 4 days, as specified in the text. The mRNA levels revealed by agarose gel electrophoresis were quantified by Image $\mathbf{J}$ and normalized to the level of hprt expression. The expression level of each transcript in CD23/ cre $; \mathrm{PP} 4^{+/+}$control mice was defined as 1 .

\section{Cytosolic/nuclear extraction and immunoblotting}

Protocol to separate cytosolic and nuclear for immunoblotting was as previously reported [47]. In brief, B cells $\left(1 \times 10^{7}\right)$ were lysed in $20 \mu$ l buffer A $(10 \mathrm{mM}$ Hepes, $10 \mathrm{mM} \mathrm{KCl}, 1.5 \mathrm{mM} \mathrm{MgCl}, 0.34 \mathrm{M}$ sucrose, $10 \%$ glycerol, $1 \mathrm{mM}$ DTT, $0.1 \%$ Triton X-100, with protease inhibitor freshly added) and left on ice for $5 \mathrm{~min}$. The lysate was centrifuged by $1300 \times \mathrm{g}, 4^{\circ} \mathrm{C}$ for $4 \mathrm{~min}$ to receive nuclei pellet. The supernatant was further clarified by $20,000 \times g, 4{ }^{\circ} \mathrm{C}$ for $15 \mathrm{~min}$ to remove cell debris and insoluble aggregates and receive the cytosolic fraction. Nuclei were washed once in buffer A, and then lysed in $30 \mu \mathrm{l}$ buffer B ( $3 \mathrm{mM}$ EDTA, $0.2 \mathrm{mM}$ EGTA, $1 \mathrm{mM}$ DTT, and freshly added protease inhibitors). After centrifugation by $1700 \times g, 4{ }^{\circ} \mathrm{C}$ for $5 \mathrm{~min}$, the yielded supernatant as nuclear fraction was collected. In-house anti-PP4 antibody was generated as described previously [42]. Antibodies recognizing p-p53 S15 (\#9284), p-ATR S428/S431 (\#2853), p-Chk1 S345 (\#2348), p-NBS1 S343 (\#3001), NBS1 (\#14956), $\gamma$ H2AX (\#9718), or H2AX (\#7631) were from Cell Signaling. Antibodies recognizing ATM (2C1), p-ATM S1981/1987 (10H11.E12), GAPDH (GTX100118), or p84 (5E10) were from GeneTex; and anti-p53 (SC-6243) was from Santa Cruz. ECL Plus ${ }^{\mathrm{TM}}$ Western Blotting Detection Reagents (Amersham) were utilized for immunoblot development. 


\section{Confocal microscopy images}

For immunofluorescence staining, B cells were fixed and permeabilized as described above. Permeabilized cells were stained on ice for $1 \mathrm{~h}$ with anti-p53-Alexa 488 (Cell Signaling \#2015), anti-RPA1-Alexa 647 (abcam \#199240), anti- $\gamma$ H2AX-Alexa 647 (Cell Signaling \#9720), or with unconjugated antibodies recognizing NBS1 (Cell Signaling \#14956) or p-p53 S15 (Cell Signaling \#9284). A secondary incubation with goat antirabbit-Alexa 488 (Invitrogen \#A11034) on ice for $1 \mathrm{~h}$ was then performed. After washing, cells were mounted onto slides using ProLong ${ }^{\text {TM }}$ Gold Antifade Mountant with DAPI (Invitrogen, P36935). Immunofluorescence was detected by confocal microscopy (Leica TCS SP5 II). Parameters such as fluorescence intensity, focus counts, and co-localization were counted by MetaMorph ${ }^{\circ}$ software.

\section{Statistical analysis}

Data were analyzed using a one-tailed distribution, type 3 Student's $t$-test. Differences between treatment groups with $P$-values $\leq 0.05$ were considered statistically significant. Symbols of p-values were defined as: $* p \leq 0.05 ;{ }^{* *} p \leq 0.005$ and $* * * p \leq 0.0005$.

\section{Results}

\section{Deletion of PP4 by CD23/cre impairs B cell division and viability}

We previously showed that $\mathrm{B}$ cells from $\mathrm{CD} 23 / \mathrm{cre} ; \mathrm{PP} 4^{\mathrm{F} / \mathrm{F}}$ mice exhibited impaired $\mathrm{B}$ cell receptor (BCR) signaling and reduced CSR efficiency [42]. To examine PP4's involvement in CSR at the molecular level, we isolated splenic B cells from control CD23/cre; $P 4^{+/+}$(wild type; WT) and mutant $\mathrm{CD} 23 / \mathrm{cre} ; \mathrm{PP} 4{ }^{\mathrm{F} / \mathrm{F}}$ mice, stimulated these cells in vitro with LPS + IL-4 for $72 \mathrm{~h}$ to induce IgG1switching, and concomitantly subjected these cells to CFSE labeling to monitor cell division. As expected, the frequency of $\mathrm{IgG} 1^{+} \mathrm{B}$ cells in the control culture increased gradually to $30 \%$ over the 2 nd to 6 th cell divisions (Figs. 1a and $1 \mathrm{~b}$ ). In the mutant culture, the frequency of $\mathrm{IgG1}^{+} \mathrm{B}$ cells was approximately $50 \%$ of the WT level at each cell division. In addition, the percentages of proliferating B cells present at the 4th to 6th cell divisions were significantly reduced in the absence of PP4, whereas cells accumulated at the 2 nd and 3rd cell divisions (Figs. 1c and 1d). Moreover, after $72 \mathrm{~h}$ of LPS + IL-4 stimulation, these PP4-deficient B cells showed a strong reduction in viability (Fig. 1e). We next examined cell cycle progression in vitro by measuring
BrdU incorporation by resting and stimulated WT and mutant B cells, and found that PP4 deficiency induced cell cycle arrest in S phase (Figs. 1f and 1g). Thus, PP4 deficiency in activated B cells leads to defects in both cell proliferation and CSR.

\section{The ATM-p53 pathway is strongly induced in PP4-deficient B cells}

To examine the consequences of PP4 deficiency in activated $\mathrm{B}$ cells at the signal transduction level, we performed immunoblotting to detect p53 phosphorylated at S15 ( $p$-p53 $\mathrm{S} 15)$ in extracts of control and $\mathrm{CD} 23 / \mathrm{cre} ; \mathrm{PP} 4^{\mathrm{F} / \mathrm{F}} \mathrm{B}$ cells that had been stimulated for 1 or 2 days with LPS + IL-4 in vitro. Indeed, $p$-p53 S15 levels were highly elevated in the mutant B cells (Fig. 2a). In addition, increased numbers of both $p$-p53 S15-foci and p53-foci were observed in cultures of etoposide-treated PP4-deficient B cells compared to WT controls (Figs. 2b and 2c; Supplementary Fig. 1). In response to DNA damage, p53 phosphorylation at S15 is catalyzed by either activated ATM or ATR [48-50]. We found that PP4-deficient B cells stimulated with anti-CD40 or LPS + IL-4 showed higher levels of p-ATM S1987 but less $p$-ATR S431 than controls (Fig. 2d). This enhanced $p$-ATM S1987 signal appeared in the mutant B cells as early as at $40 \mathrm{~h}$ post-stimulation revealed by intracellular staining (Fig. 2e). These results suggest that, in response to LPS + IL-4, PP4-deficient B cells activate the ATM-p53 axis to trigger a vigorous DNA damage response.

\section{Induction of p53 facilitates CSR in PP4-deficient mature $B$ cells by promoting cell survival}

To explore p53's role in Ig class switching, we generated $\mathrm{CD} 23 / \mathrm{cre} ; \mathrm{PP} 4{ }^{\mathrm{F} / \mathrm{F}} \mathrm{p} 53^{\mathrm{F} / \mathrm{F}}$ mice and control littermates. We stimulated B cells from CD23/cre; $\mathrm{PP} 4^{+/+}, \mathrm{CD} 23 / \mathrm{cre}_{\mathrm{PP}}{ }^{\mathrm{F} / \mathrm{F}}$, $\mathrm{CD} 23 / \mathrm{cre} ; \mathrm{PP} 4^{\mathrm{F} / \mathrm{F}} \mathrm{p} 53^{\mathrm{F} / \mathrm{F}}$, and $\mathrm{CD} 23 / \mathrm{cre} ; \mathrm{p} 53^{\mathrm{F} / \mathrm{F}}$ mice with LPS + IL-4 in vitro and measured CSR efficiency. Double deficiency of PP4 and p53 increased the severity of the defects in $\mathrm{IgG} 1^{+}$-switching and $\mathrm{IgG} 3^{+}$-switching compared to loss of PP4 alone (Figs. $3 \mathrm{a}$ and $3 \mathrm{~b}$ ), suggesting that p53 induction in PP4-deficient $\mathrm{B}$ cells protects CSR.

We next applied CFSE labeling to our double mutant B cells and found that their proliferation was still compromised (Fig. 3c). We then performed retroviral transduction of $\mathrm{B}$ cells from $\mathrm{CD} 23 / \mathrm{cre} ; \mathrm{PP} 4{ }^{\mathrm{F} / \mathrm{F}} \mathrm{p} 53^{\mathrm{F} / \mathrm{F}}$ mice to achieve ectopic expression of either PP4 WT, PP4 phosphatase-dead mutant R236L [51], p53 WT, p53 S15A, or p21, and subjected these cells to stimulation with LPS + IL- 4 for $72 \mathrm{~h}$ in vitro. Double mutant B cells transduced with PP4 showed increased viability compared to mock-transduced controls, whereas transduction of PP4 R236L, p53, or p21 impaired cell survival (Fig. 3d). Intriguingly, transduction of p53 


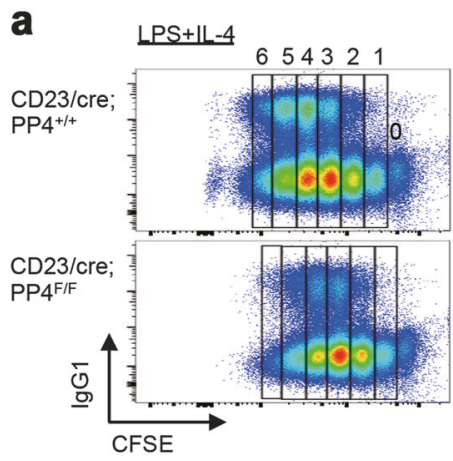

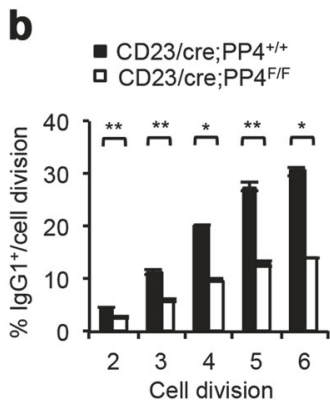

c

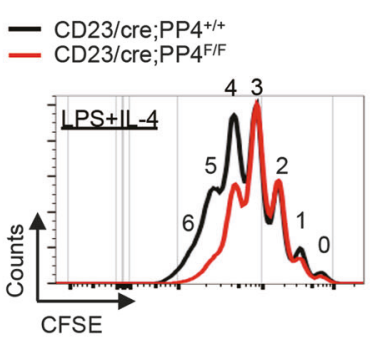

d

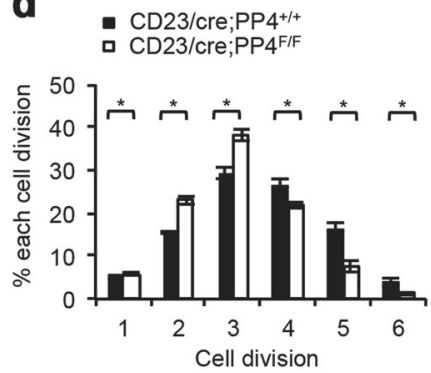

$\mathbf{f}$
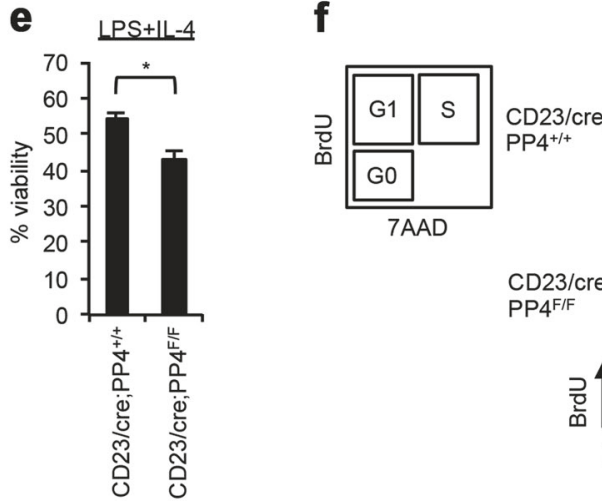

;

Mediu

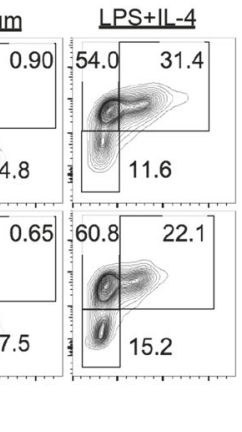

g
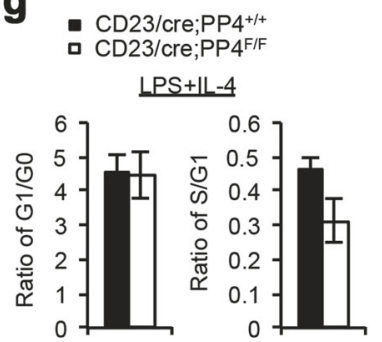

Fig. 1 Reduced Ig class switch efficiency is associated with impaired cell division in PP4-deficient B cells. a FACS profiles of CFSE decay versus $\mathrm{IgG1}$ expression by $\mathrm{B}^{2} 20^{+} \mathrm{IgM}^{-} \operatorname{IgD}{ }^{-}$gated $\mathrm{B}$ cells that were isolated from mice of the indicated genotypes ( $n=3$ /group) and stimulated with LPS + IL-4 for $72 \mathrm{~h}$ in vitro. Numbers 0 to 6 indicate cell divisions. Data are representative of three independent experiments. b Quantitation of frequencies of $\mathrm{IgG1}^{+}$-switched B cells after the 2nd to 6th cell divisions among the $\mathrm{B} 220^{+} \operatorname{IgM}^{-} \operatorname{IgD}^{-}$gated $\mathrm{B}$ cells in the experiment described in a. Data are the mean \pm SD of triplicates. $* p \leq 0.05 ; * * \leq 0.005$. c Overlay of CFSE decay curve and proliferation curve as determined by FACS for the proliferating B cells in a. Data are representative of two independent trials. $\mathbf{d}$ Quantitation of the percentage of proliferating cells in the 1 st to 6th cell divisions of the $\mathrm{B}$ cells in a. Data are the mean $\pm \mathrm{SD}$ ( $n=3$ /group). e Quantitation of the percentage of viable B cells stimulated with LPS + IL-4 for $72 \mathrm{~h}$ in a. Data are the mean \pm SD ( $n=3$ /group). f Left: Schematic illustration $n$ of cell cycle phases in a FACS profile. Right: FACS profiles showing BrdU incorporation by purified $\mathrm{B}$ cells of the indicated genotypes that were stimulated with LPS + IL-4 for $72 \mathrm{~h}$ in vitro. Numbers in quadrants are frequencies of BrdU/7AAD-positive cells in each phase, as indicated. Data are representative of three independent trials. g Quantitation of the ratio of cells in G1 versus G0 phase (left) or in S versus G1 phase (right) in the experiment described in $\mathbf{f}$. Data are the mean $\pm \mathrm{SD}$ ( $n=3$ /groups)
S15A reduced cell viability more severely than transduction of p53 WT or p21, suggesting that the cell cycle arrest induced by the p53-p21 pathway contributes to mutant B cell survival. However, only double mutant B cells transduced with PP4 WT were able to undergo IgG1-switching and proliferate until the 6th cell division (Figs. 3e and 3f; Supplementary Fig. 2). These findings suggest that p53 activation in PP4-deficient B cells is beneficial for CSR because it promotes cell survival through induction of cell cycle arrest.

\section{Impaired ATR activation and reduced YH2AX-NBS1 complex formation in PP4-deficient B cells}

ATR is a master conductor of cellular responses to DNA replication stress. Upon activation, mouse ATR is phosphorylated at several residues, including S431 (equivalent to human ATR S428) [52, 53]. Activated ATR further phosphorylates Chk1 on S345, that induces cell cycle arrest [54]. To dissect the signaling events responsible for the proliferation defect in PP4-deficient B cells, we stimulated $\mathrm{CD} 23 / \mathrm{cre} ; \mathrm{PP} 4^{+/+}$and $\mathrm{CD} 23 / \mathrm{cre} ; \mathrm{PP} 4{ }^{\mathrm{F} / \mathrm{F}} \mathrm{B}$ cells with LPS + IL-4 in vitro for $24 \mathrm{~h}$ or $48 \mathrm{~h}$, and subjected cytosolic and nuclear lysates to immunoblotting to detect $p$-ATR S431. In control B cells, LPS + IL-4 stimulation induced ATR S431 phosphorylation on day 1 , followed by a decrease in this phosphorylation signal by $48 \mathrm{~h}$ (Fig. 4a). However, PP4-deficient B cells did not induce $p$-ATR S431 signal upon stimulation for $24 \mathrm{~h}$ nor $48 \mathrm{~h}$. Consistent with this, LPS + IL-4 induced Chk1 S345-phosphorylation in control cells on $24 \mathrm{~h}$ after stimulation, which was with the same kinetic as ATR activation. However, the inducible Chk1-phosphorylation on S345 on $24 \mathrm{~h}$ post stimulation was absent in PP4-deficient B cells (Fig. 4a). The results reveal that PP4 deficiency impairs the activation of ATRChk1 pathway. 

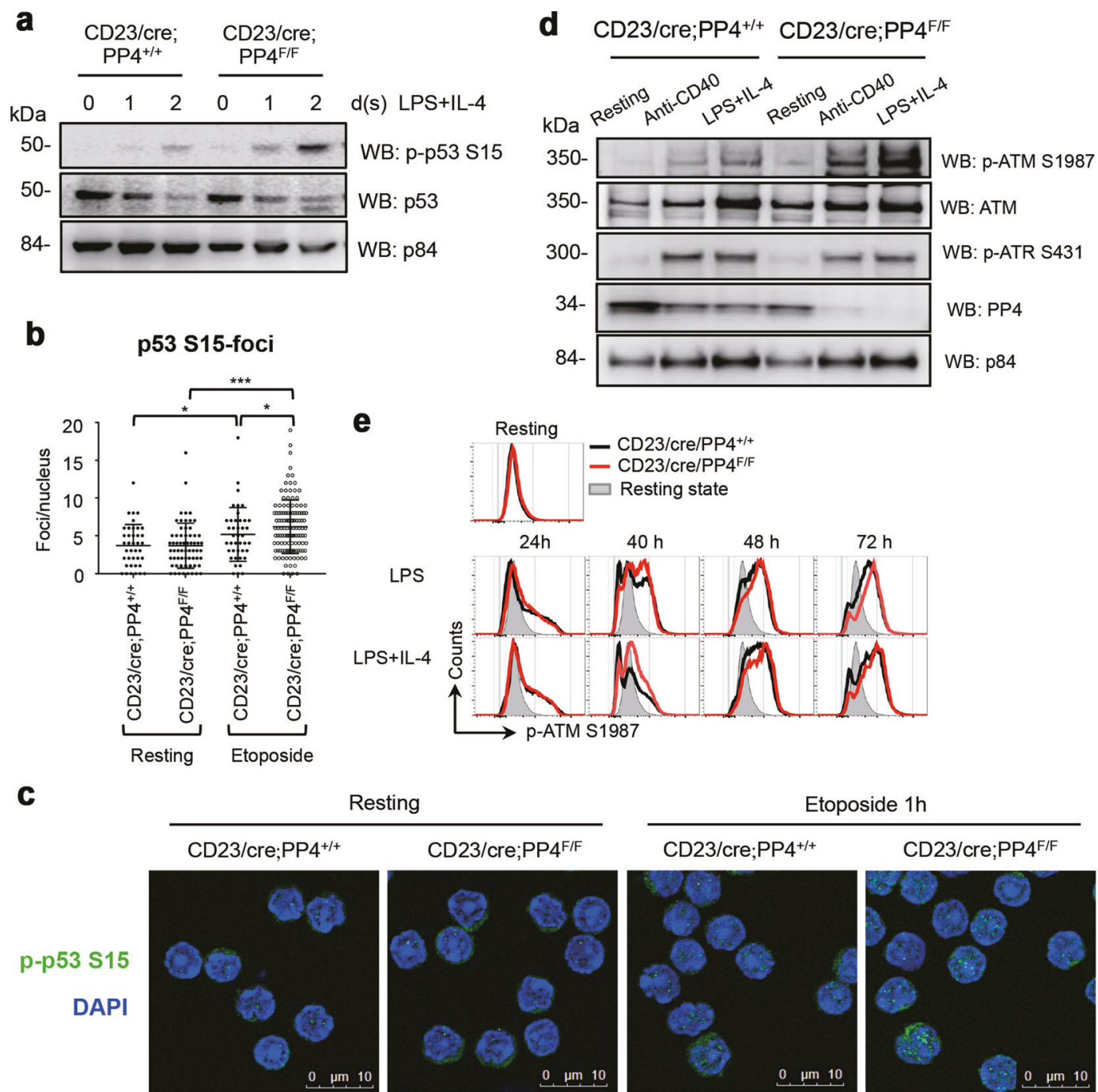

Resting

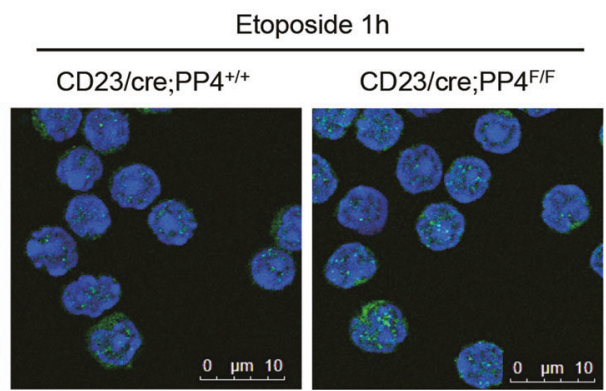

Fig. 2 The ATM-p53 pathway is strongly induced in PP4-deficient B cells. a Immunoblots to detect phospho-p53 ( $p$-p53) S15, total p53 and p84 (nuclear loading control) in the nuclear fraction of splenic B cells that were isolated from mice of the indicated genotypes ( $n=3$ /group) and left unstimulated (0), or stimulated with LPS + IL-4 for 1 or 2 days. Data are representative of two independent trials. b Quantitation of the number of nuclear $p$-p53 S15-foci/cell in purified splenic $\mathrm{B}$ cells that were isolated from mice of the indicated genotypes and were left untreated (resting) or treated with $10 \mu \mathrm{M}$ etoposide for $1 \mathrm{~h}$ in vitro. Data are values for individual mice ( $n=3$ /group). Horizontal bars $=$ mean values $\pm \mathrm{SD}$ (cell number 39-126/group). $* p \leq 0.05$.
$* * * p \leq 0.0005$. c Representative confocal microscopy images of cells in the experiment described in $\mathbf{b}$. Data are representative of two independent trials. d Immunoblots to detect phospho-ATM ( $p$-ATM) S1987, total ATM, $p$-ATR S431, total ATR, and p84 in the nuclear fraction of B cells of the indicated genotypes that were left untreated (resting) or were stimulated with anti-CD40 or LPS + IL-4 for 4 days. Data are representative of two independent trials. e Curve overlay to show intracellular staining to detect $p$-ATM S1987 in B cells of the indicated genotypes that were left untreated (resting) or stimulated with LPS or LPS + IL-4 for the indicated times. Data are representative of two independent trials
During DNA damage, NBS1 and H2AX are phosphorylated by ATM or ATR and recruited to DNA damage sites [4] [55-57]. We therefore used immunoblotting to determine whether PP4 deficiency affected nuclear localization of NBS1 and $\gamma \mathrm{H} 2 \mathrm{AX}$ in activated B cells. In the resting status, a low level of NBS1 was detectable in the nuclear fraction of WT and PP4-deficient B cells. Upon $24 \mathrm{~h}$ after stimulation with LPS + IL-4, NBS1 became strongly phosphorylated on S343 and accumulated in WT nucleus. The $p$-NBS1 S343 signal dropped in WT nucleus at $48 \mathrm{~h}$ post-stimulation, which was associated with downregulation of total NBS1 protein (Fig. 4a). Although $p$-NBS1 S343 was detected in the cytosol of PP4-deficient B cells, the nuclear translocation of $p$-NBS1 S343 was severely blocked. These results suggest that PP4 is necessary for the nuclear translocation of NBS1 and normal activation of ATR-Chk1 pathway in response to signals triggering Ig class switching.

During DNA replication, RPA proteins are recruited to single-stranded lesions in DNA to stabilize the stalled 
a

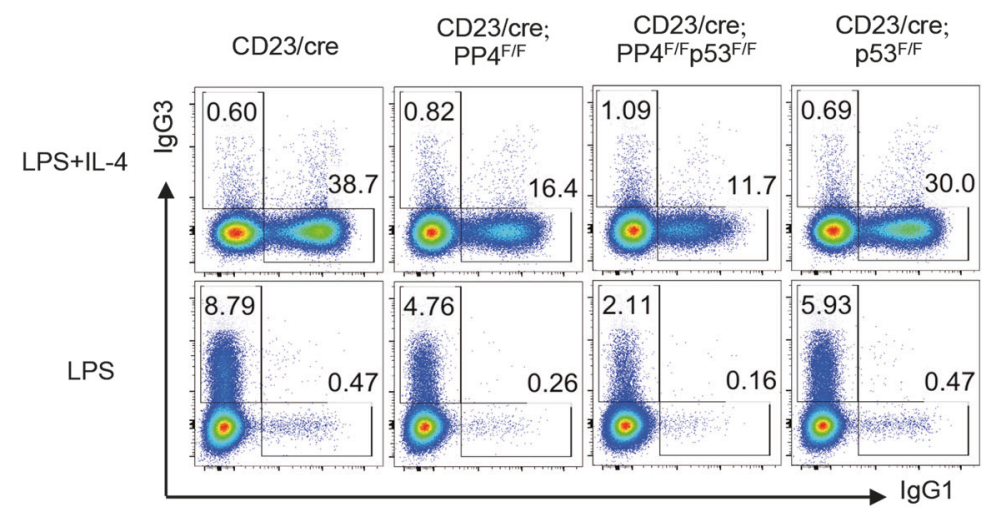

b
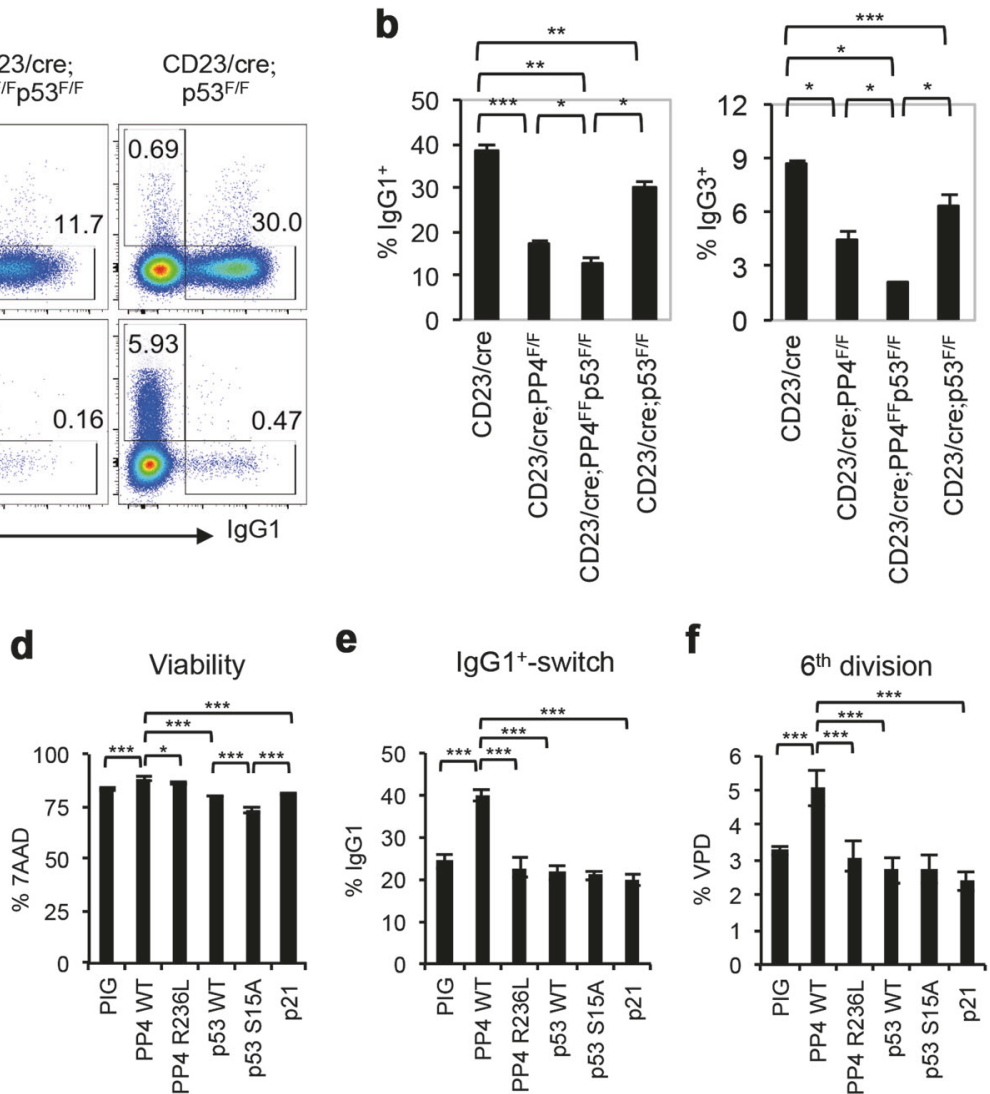

$\mathbf{e}$

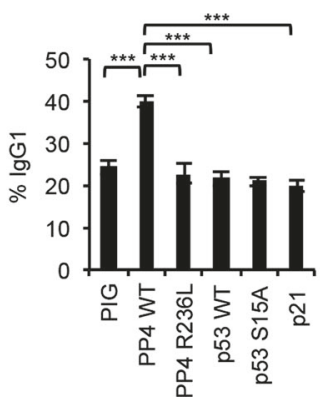

$\mathbf{f}$

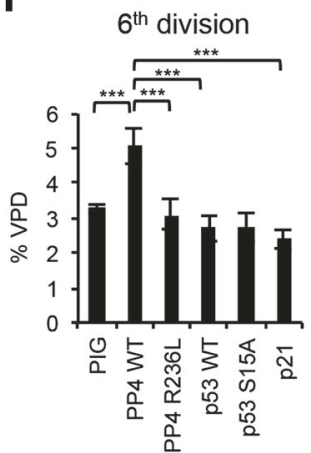

Fig. 3 Induction of p53 facilitates CSR in PP4-deficient mature B cells by promoting cell survival. a FACS profiles of IgG1 versus IgG3 expression by $\mathrm{B}_{22} 20^{+} \mathrm{IgM}^{-} \mathrm{IgD}^{-}$gated B cells that were isolated from mice of the indicated genotypes ( $n=3 /$ group) and stimulated in vitro with LPS + IL-4 or LPS for $72 \mathrm{~h}$. Data are representative of three independent trials. b Quantitation of the percentage of $\mathrm{IgG1} 1^{+}$- and IgG3 ${ }^{+}$-switched B cells among total B cells stimulated by LPS + IL-4 (left) and LPS (right) from the data in a. Data are the mean $\pm \operatorname{SD}(n=$ 3/group). c Curve overlay to show CFSE decay in B cells in (top) $\mathrm{CD} 23 / \mathrm{cre}_{\mathrm{PP}}{ }^{+/+}$versus $\mathrm{CD} 23 / \mathrm{cre} ; \mathrm{PP} 4^{\mathrm{F} / \mathrm{F}}$, and (bottom) $\mathrm{CD} 23 / \mathrm{cre}$; $\mathrm{p} 53^{\mathrm{F} / \mathrm{F}}$ versus $\mathrm{CD} 23 / \mathrm{cre} ; \mathrm{PP} 4^{\mathrm{F} / \mathrm{F}} / \mathrm{p} 53^{\mathrm{F} / \mathrm{F}}$ cultures that were stimulated

forks and signal for ATR activation [9, 10]. In addition, a direct interaction between RPA1 and MRN complex has been demonstrated [58]. To address whether the impaired nuclear translocation of NBS1 in PP4-deficient B cells was associated with a reduction of RPA-foci formation, we performed immunofluorescent staining to detect nuclear RPA1 in CD23/cre;PP4 ${ }^{+/+}$and CD23/cre;PP4 ${ }^{\mathrm{F} / \mathrm{F}} \mathrm{B}$ cells that were left untreated or stimulated with LPS + IL-4 for $24 \mathrm{~h}$. In resting control B cells, RPA1 was enriched in the nucleus and appeared as coarse particles (Fig. 4b). Stimulation by LPS + IL-4 slightly increased the intensity of nuclear RPA1 staining, which appeared "cloudy" and more widely distributed than in unstimulated WT cells. Although the morphology of nuclear RPA1 in resting or stimulated PP4-deficient B cells was similar to that in the WT controls, the intensity of RPA1 staining in PP4-deficient B cells was much less in both cases (Fig. 4b). These findings indicate with LPS + IL-4 for $72 \mathrm{~h}$. Numbers 0 to 6 indicate cell divisions. Data are representative of two independent trials. d Quantitation of percent viability as determined by 7AAD staining among $\mathrm{GFP}^{+} \mathrm{B}$ cells that had been retrovirally transduced with pMSCV-PIG empty vector, or vectors encoding PP4 WT, PP4 R236L, p53 WT, p53 S15A, or p21, as indicated. Data are the mean $\pm \mathrm{SD}(n=4 /$ group). e Quantitation of the percentage of IgG1-switched $\mathrm{GFP}^{+} \operatorname{IgM}^{-} \mathrm{IgD}^{-}$cells among the transduced B cells in d. Data are the mean $\pm \mathrm{SD}(n=4 /$ group). f Quantitation of $\%$ VPD-positive cells at the $6^{\text {th }}$ cell division among the transduced B cells in d. Data are the mean $\pm \mathrm{SD}$ ( $n=4$ /group)

that PP4 deficiency in B cells reduces RPA1 recruitment, potentially weakening ATR activation.

The above results prompted us to use confocal microscopy to examine the effect of PP4 deficiency on $\gamma \mathrm{H} 2 \mathrm{AX}$ foci induced in response to LPS + IL-4. Although PP4 has been demonstrated to function as a $\gamma \mathrm{H} 2 \mathrm{AX}$-phosphatase that is required for the recovery from DNA damage [3335], we did not observe any significant accumulation of $\gamma \mathrm{H} 2 \mathrm{AX}$ in PP4-deficient B cells in the resting status or on $24 \mathrm{~h}$ post stimulation with LPS + IL-4 (Fig. 4a). Due to mitotic effect driven by LPS, the appearance of H2AX in the cytosolic fractions, especially on $48 \mathrm{~h}$ post stimulation, reflected an increased amount of cells in prometaphase. Indeed, cultures of PP4-deficient B cells showed many fewer $\gamma \mathrm{H} 2 \mathrm{AX}$-foci than cultures of WT B cells at $48 \mathrm{~h}$ post-stimulation with LPS + IL-4 (Fig. 4c). Although NBS1-focus formation was comparable between WT and 
a

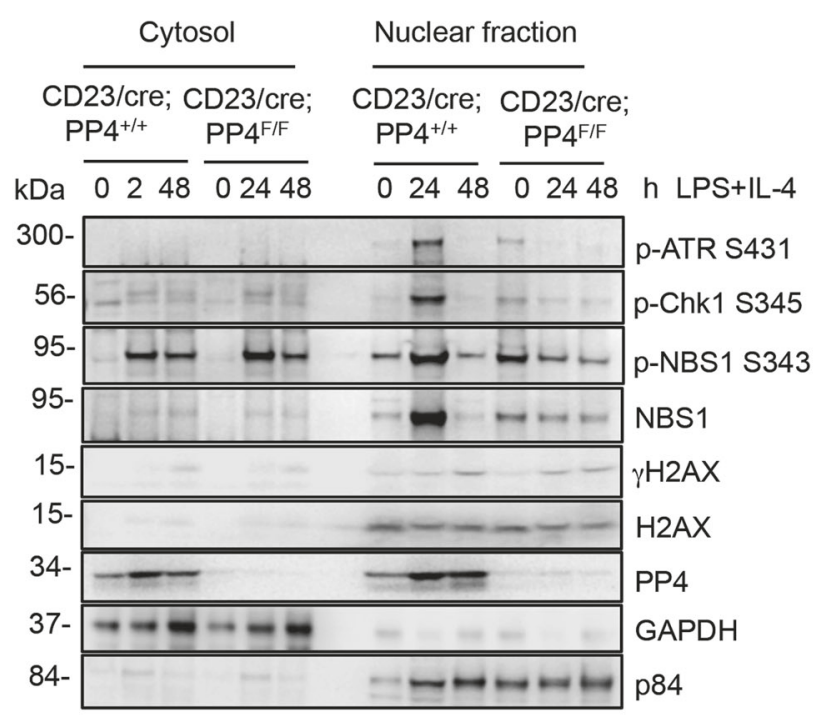

C

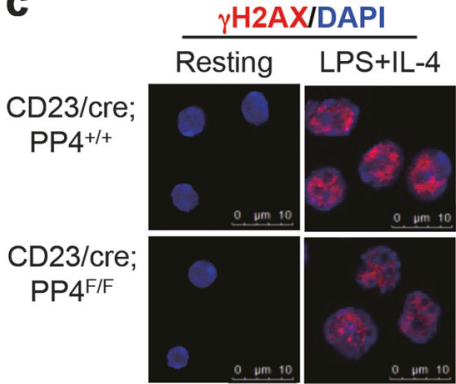

$\gamma \mathrm{H} 2 \mathrm{AX}$-foci

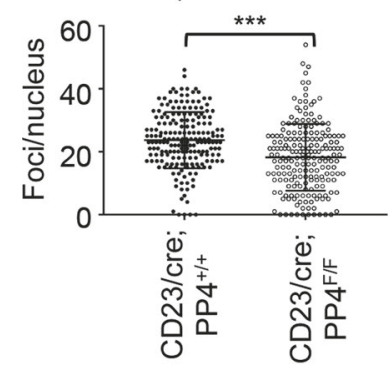

Fig. 4 Deletion of PP4 by CD23/cre reduces CSR efficiency. a Immunoblots to detect $p$-ATR S431, $p$-Chk1 S345, p-NBS1 S343, NBS1, $\gamma \mathrm{H} 2 \mathrm{AX}, \mathrm{H} 2 \mathrm{AX}, \mathrm{PP} 4, \mathrm{GAPDH}$ and $\mathrm{p} 84$ in the cytosolic and nuclear fractions of $\mathrm{B}$ cells of the indicated genotypes that were left unstimulated (0), or stimulated with LPS + IL-4 for $24 \mathrm{~h}$ or $48 \mathrm{~h}$. Data are representative of two independent trials. b Confocal microscopy images of immunofluorescent staining to detect RPA1 and quantitation of the intensity of RPA1 stainining in B cells of the indicated genotypes that were left untreated (resting) or stimulated with LPS + IL-4 for $24 \mathrm{~h}$. c Confocal microscopy images of immunostaining to detect

PP4-deficient B cells, the co-localization of $\gamma \mathrm{H} 2 \mathrm{AX}-\mathrm{NBS} 1$ signals was significantly reduced in PP4-deficient B cells at $48 \mathrm{~h}$ post-stimulation (Figs. $4 \mathrm{~d}$ and $4 \mathrm{e}$ ). Thus, PP4 b
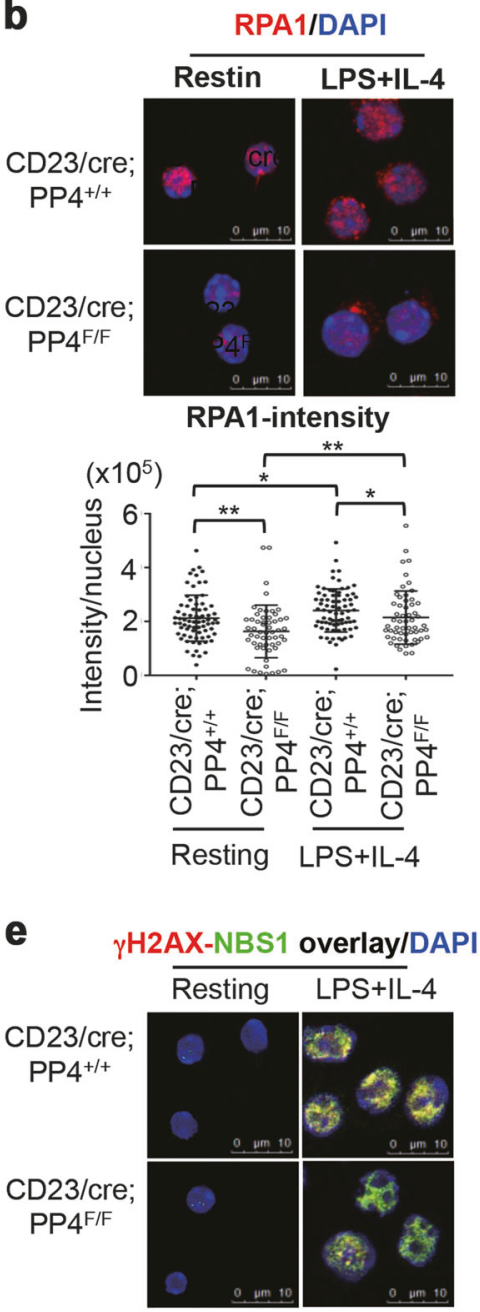

Co-localized $\gamma \mathrm{H}$ 2AX-NBS1

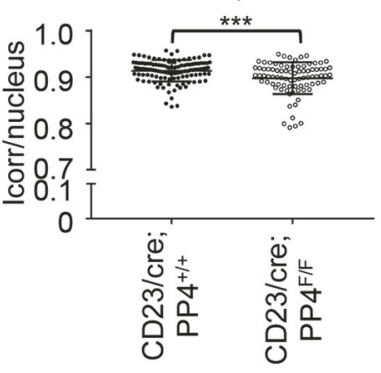

$\gamma \mathrm{H} 2 \mathrm{AX}$ (red) and quantitation of $\gamma \mathrm{H} 2 \mathrm{AX}$-foci in B cells of the indicated genotypes that were left untreated (resting) or stimulated with LPS + IL-4 for $48 \mathrm{~h}$. d Confocal microscopy images of immunostaining to detect NBS1 (green) and quantitation of NBS1-foci in the experiment described in c. e Confocal microscopy images of immunostaining to detect $\gamma \mathrm{H} 2 \mathrm{AX}$ overlaid with NBS1 and quantitation of colocalized $\gamma \mathrm{H} 2 \mathrm{AX}-\mathrm{NBS} 1$ foci (index of correlation, Icorr) in the experiment described in $\mathbf{c}$. Horizontal line $=$ mean \pm SD. Data from b-e are analyzed by MetaMorph. Values are for individual cells, and representative of two independent experiments. ns, not significant

deficiency in B cells reduces the retention of $\gamma \mathrm{H} 2 \mathrm{AX}-\mathrm{NBS} 1$ complexes and impairs ATR-Chk1 activation on DNA damage sites. 


\section{Deletion of PP4 by AID/cre does not impair CSR in vitro}

Our data indicated that the defective CSR in PP4-deficient $\mathrm{B}$ cells was associated with their proliferation defect. We therefore investigated whether deletion of PP4 mediated by $\mathrm{AID} / \mathrm{cre}$ in GC B cells, which affects the stage beyond cellular proliferation, could restore normal CSR efficiency. We generated AID/cre; $P P 4^{+/+}$and $\mathrm{AID} / \mathrm{cre}^{\mathrm{PPP}}{ }^{\mathrm{F} / \mathrm{F}}$ mice, purified splenic $B$ cells from these animals, and examined IgG1-switching following LPS + IL-4 stimulation of these $\mathrm{B}$ cells in vitro. The efficiency of PP4 deletion induced by AID/cre was approximately $60 \%$ at $72 \mathrm{~h}$ post-stimulation (Fig. 5a). Within the first 6 cell divisions, B cells from AID/ cre;PP4 ${ }^{+/+}$and $\mathrm{AID} / \mathrm{cre} ; \mathrm{PP} 4^{\mathrm{F} / \mathrm{F}}$ mice showed an equal ability to generate IgG1-expressing B cells (Figs. 5b and 5c). Examination of total $B$ cell frequencies through the 1st to 6th cell divisions showed that the cell cycling of LPS + IL-4-stimulated AID/cre; $\mathrm{PP} 4{ }^{\mathrm{F} / \mathrm{F}}$ B cells was comparable to that of AID/cre;PP4 ${ }^{+/+}$controls (Figs. $5 \mathrm{~d}$ and $5 \mathrm{e}$ ), as was their viability (Fig. 5f). We then monitored the frequency of IgG1-switching in LPS + IL-4-stimulated B cells at $24 \mathrm{~h}$ intervals over 2 to 6 days of culture and found no differences between the genotypes (Fig. $5 \mathrm{~g}$ ). Thus, deletion of PP4 after the cell proliferation phase does not affect class switching in vitro.

To study the effect of AID/cre-induced PP4 deficiency on CSR in vivo, we immunized AID/cre; $\mathrm{PP}^{+/+}$and AID/ cre; $\mathrm{PP} 4^{\mathrm{F} / \mathrm{F}}$ mice with TNP-KLH emulsified in alum and compared the proportion of $\mathrm{IgG}^{+} \mathrm{B}$ cells present at 14 days post-immunization with that in PBS-immunized controls. In AID/cre; $\mathrm{PP}^{+/+}$mice, $\mathrm{IgG1}{ }^{+} \mathrm{B}$ cells increased from $1.3 \%$ to $8.7 \%$ after immunization (Figs. $5 \mathrm{~h}$ and $5 \mathrm{i}$ ). However, IgG1 ${ }^{+} \mathrm{B}$ cells were poorly induced in immunized $\mathrm{AID} / \mathrm{cre} ; \mathrm{PP} 4^{\mathrm{F} / \mathrm{F}}$ mice and only increased from $0.52 \%$ to $1.54 \%$. We then generated AID/cre; $\mathrm{p} 53^{\mathrm{F} / \mathrm{F}}$ and AID/cre; $\mathrm{PP} 4{ }^{\mathrm{F} / \mathrm{F}} \mathrm{p} 53^{\mathrm{F} / \mathrm{F}}$ mice to investigate whether a double deficiency of PP4 and p53 mediated by AID/cre could influence IgG1-switching upon TNP-KLH-immunization in vivo. Remarkably, $\mathrm{IgG}^{+} \mathrm{B}$ cells in immunized AID/cre; $\mathrm{PP} 4^{\mathrm{F} /}$ ${ }_{\mathrm{F}} 5^{\mathrm{F} / \mathrm{F}}$ mice rose from $0.9 \%$ to $4.2 \%$, an almost 3 -fold increase over the level of these cells in immunized AID/cre; $\mathrm{PP} 4{ }^{\mathrm{F} / \mathrm{F}}$ mice (Figs. $5 \mathrm{~h}$ and $5 \mathrm{i}$ ). These results show that deletion of PP4 by AID/cre completely rescues CSR in vitro, and that ablation of both PP4 and p53 by AID/cre can partially rescue IgG1-switching in vivo.

\section{Deletion of p53 promotes the production of germline transcripts}

The production of donor and acceptor germline transcripts is a prerequisite for CSR. To determine why p53 deletion rescued CSR in PP4-deficient B cells, we used semi- quantitative RT-PCR to determine levels of the $\mathrm{C} \mu, \mathrm{C} \gamma 1$, and $\mathrm{S} \mu-\mathrm{S} \gamma 1$ germline transcripts in B cells from CD23/cre; $\mathrm{PP}^{+/+}{ }^{+1}, \mathrm{CD} 23 / \mathrm{cre} ; \mathrm{PP} 4{ }^{\mathrm{F} / \mathrm{F}}, \mathrm{CD} 23 / \mathrm{cre} ; \mathrm{PP}^{\mathrm{F} / \mathrm{F}} \mathrm{p} 53^{\mathrm{F} / \mathrm{F}}$, and $\mathrm{CD} 23 / \mathrm{cre} ; \mathrm{p} 53^{\mathrm{F} / \mathrm{F}}$ mice. In the same experiment, we measured relative mRNA levels of aicda, pp4, p53, and hprt (control) in these cells (Fig. 6a). Quantitative analysis of the relative expression of these transcripts revealed that levels of each transcript examined (except p53) were significantly reduced in the absence of PP4 alone (Fig. 6b). Notably, loss of both PP4 and p53 restored normal levels of germline transcript $\mathrm{C} \gamma 1$ and aicda mRNA (Figs. 6a and 6b). These findings suggest that PP4 is required for normal germline transcript production, that p53 exerts a suppressive effect on CSR, and that inactivation of $\mathrm{p} 53$ promotes the generation of germline acceptor transcripts.

Taken together, our data indicate that PP4 deficiency decreases ATR activation and thereby reduces the retention of $\gamma \mathrm{H} 2 \mathrm{AX}-\mathrm{NBS} 1$ complexes on DNA damage sites, leading to p53 activation and a sustained DNA damage response (Fig. 7). However, deletion of PP4 after B cells have proliferated rescues CSR in vitro. In vivo, ablation of PP4 and p53 at the GC B cell stage by AID/cre partially rescues CSR through the increased sustained production of germline acceptor transcripts.

\section{Discussion}

In this study, we demonstrate that PP4 is essential for the avoidance of DNA replication stress, whose prevention is a prerequisite for CSR. In response to LPS + IL-4, substances that induce class switching to IgG1, PP4-deficient B cells show a defect in cell proliferation due to cell cycle arrest in S phase, as well as reduced cell survival. We find that PP4 deficiency strongly reduces RPA1 intensity and affects the nuclear translocation of NBS1 upon the LPS + IL-4. ATR-Chk1 pathway is thus not well activated in LPS + IL-4-stimulated B cells lacking PP4, and the number of $\gamma \mathrm{H} 2 \mathrm{AX}-\mathrm{NBS} 1$-foci retained at sites of DNA damage is decreased. It is likely that the reduced B cell proliferation and $\mathrm{S}$ phase arrest reflects the attenuated ATR signaling pathway in the absence of PP4. Severe DNA damage accumulates that then induces strong activation of the ATM-p53 pathway. However, when PP4 is deleted by AID/cre at GC B cell stage, which is beyond the cell proliferation phase, IgG1-switching is completely restored to normal in vitro. In vivo, however, genetic ablation of PP4 by AID/cre fails to rescue class switching. We have previously shown that PP4 deficiency affects BCR signaling and antigen-specific clonal expansion in vivo [42]. Thereby, we speculate that this defect in IgG1-switching is an indirect consequence of the impaired $\mathrm{GC}$ formation evident in immunized AID/cre; $\mathrm{PP} 4^{\mathrm{F} / \mathrm{F}}$ mice 
a

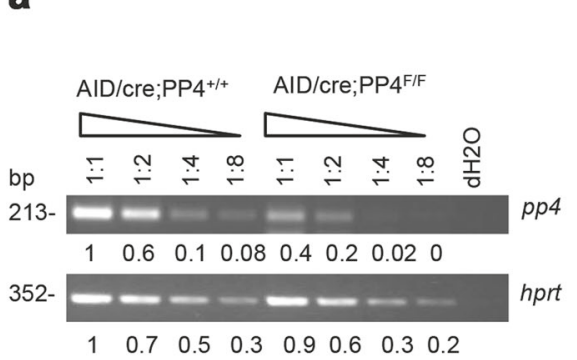

b

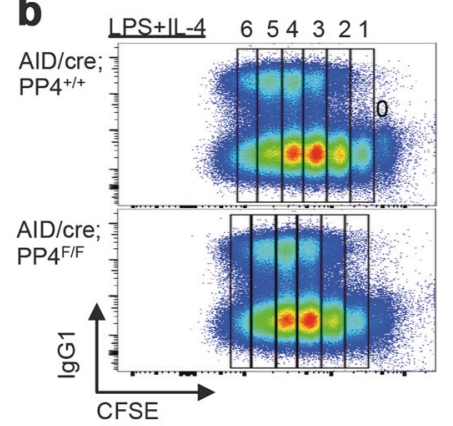

C

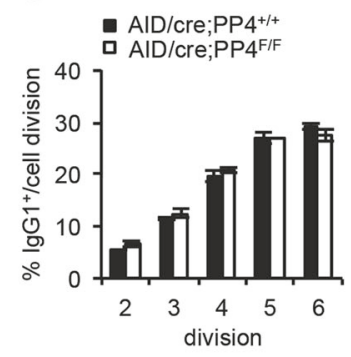

d

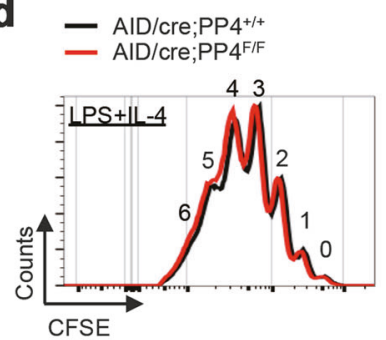

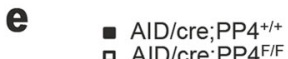

드 40

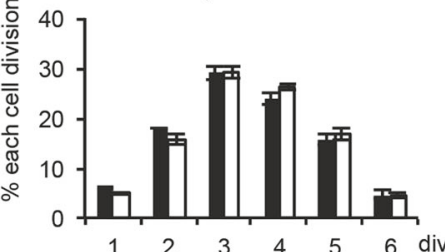

f
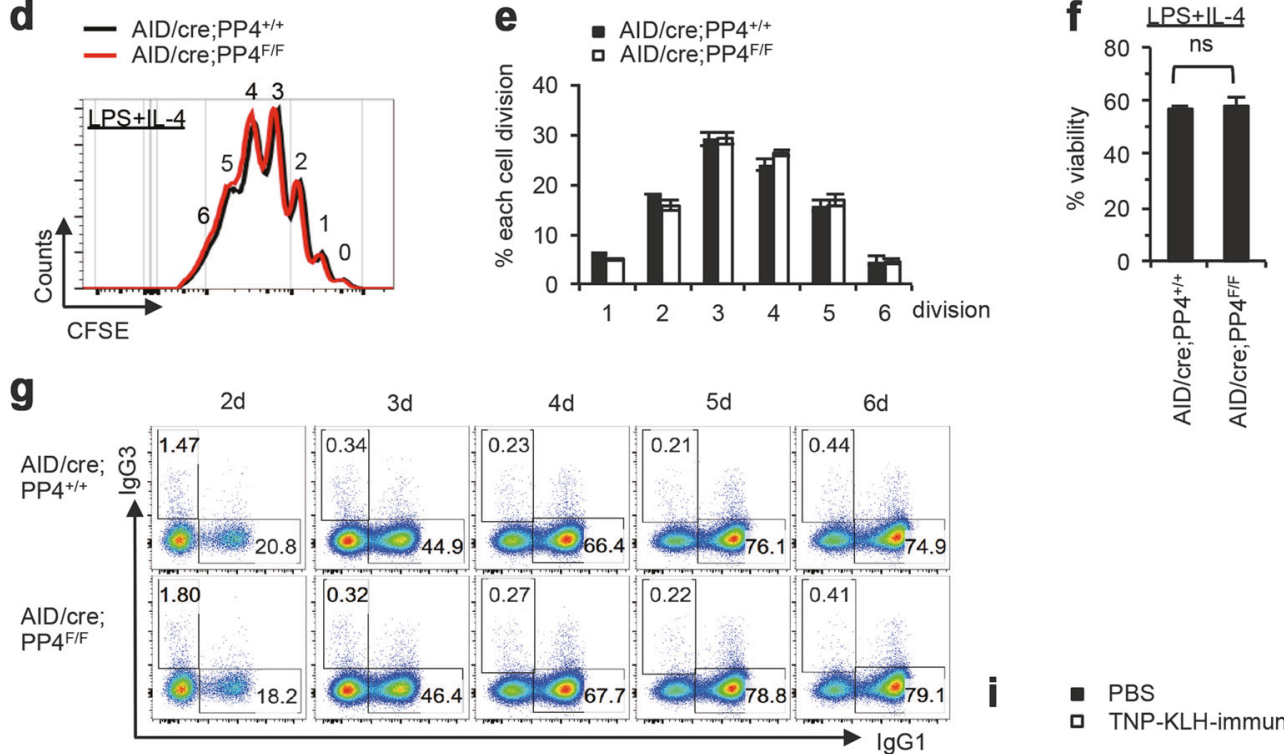

i - PBS

口 TNP-KLH-immunization

h
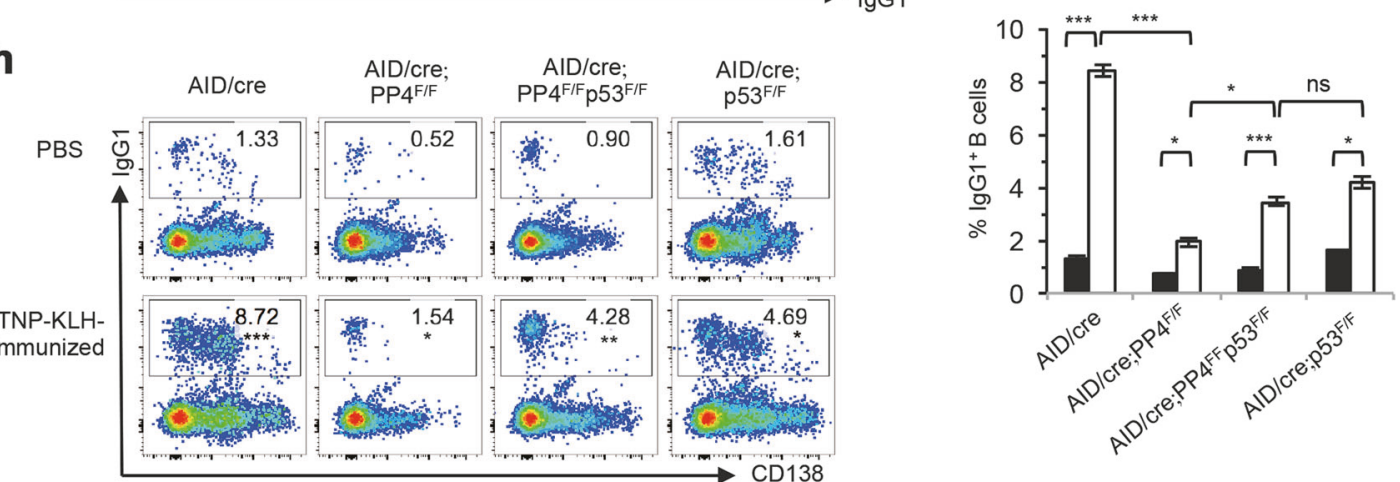

Fig. 5 Deletion of PP4 by AID/cre restores B cell proliferation and IgG1-switching in vitro. a Semi-quantitative RT-PCR analysis of $p p 4$ mRNA expression in B cells of the indicated genotypes that were stimulated with LPS + IL-4 for $72 \mathrm{~h}$ in vitro. Extracts were diluted as indicated. hprt, loading control. Data are representative of two independent trials. b FACS profiles of CFSE decay versus IgG1 expression in $\mathrm{B}_{22} 20^{+} \mathrm{IgM}^{-} \mathrm{IgD}-$ gated $\mathrm{B}$ cells of the indicated genotypes that were stimulated with LPS + IL-4 for $72 \mathrm{~h}$ in vitro. Numbers $1-6$ indicate cell divisions. Data are representative of three independent experiments. c Quantitation of IgG1-switched B cells at the 2nd to 6th cell divisions among the $\mathrm{B}_{2} 20^{+} \mathrm{IgM}^{-} \mathrm{IgD}^{-}$gated $\mathrm{B}$ cells in the experiment described in $\mathbf{b}$. Data are the mean \pm SD of triplicates. d CFSE overlay of proliferating B cells in the experiment described in $\mathbf{b}$. Data are representative of three independent trials. e Quantitation of frequencies of proliferating B cells at the 1st to 6th cell divisions in the experiment described in b. Data are the mean $\pm \mathrm{SD}$ ( $n=4$ /group). f Quantitation of percent viability for the $\mathrm{B}$ cells in the experiment described in $\mathbf{b}$. g FACS profiles of the kinetics of induction of IgG1 versus IgG3 expression by $\operatorname{IgM}^{-} \mathrm{IgD}^{-}$gated $\mathrm{B}$ cells of the indicated genotypes stimulated with LPS + IL-4 for 2 to 6 days in vitro, as indicated. Data are representative of two independent experiments. h FACS profiles of $\mathrm{CD} 138$ versus $\mathrm{IgG} 1$ expression by $\operatorname{IgM}^{-} \operatorname{IgD}{ }^{-}$gated $\mathrm{B}$ cells that were isolated from mice of the indicated genotypes on day 14 post-immunization with TNP-KLH. Data are representative of two independent experiments. i Quantitation of the percentage of $\operatorname{IgG} 1^{+}$ $\mathrm{B}$ cells in the experiment described in $\mathbf{h}$. Data are the mean \pm SD ( $n=3-5$ /group) 
Fig. 6 p53 deficiency restores normal levels of germline transcript $\mathrm{C} \gamma 1$. a RT-PCR analysis of $\mathrm{B}$ cells that were isolated from mice of the indicated genotypes $(n=4 /$ group) and stimulated in vitro with LPS + IL-4 for $72 \mathrm{~h}$. Extracts were diluted as indicated and analyzed to detect switched transcript $\mathrm{S} \mu-\mathrm{S} \gamma 1$, germline transcripts $\mathrm{C} \mu$ and $\mathrm{C} \gamma 1$, and $p p 4, p 53$, aicda, and hprt mRNAs. Data are representative of two independent trials. b Quantitation of fold change in the levels of the transcripts in the experiment described in a

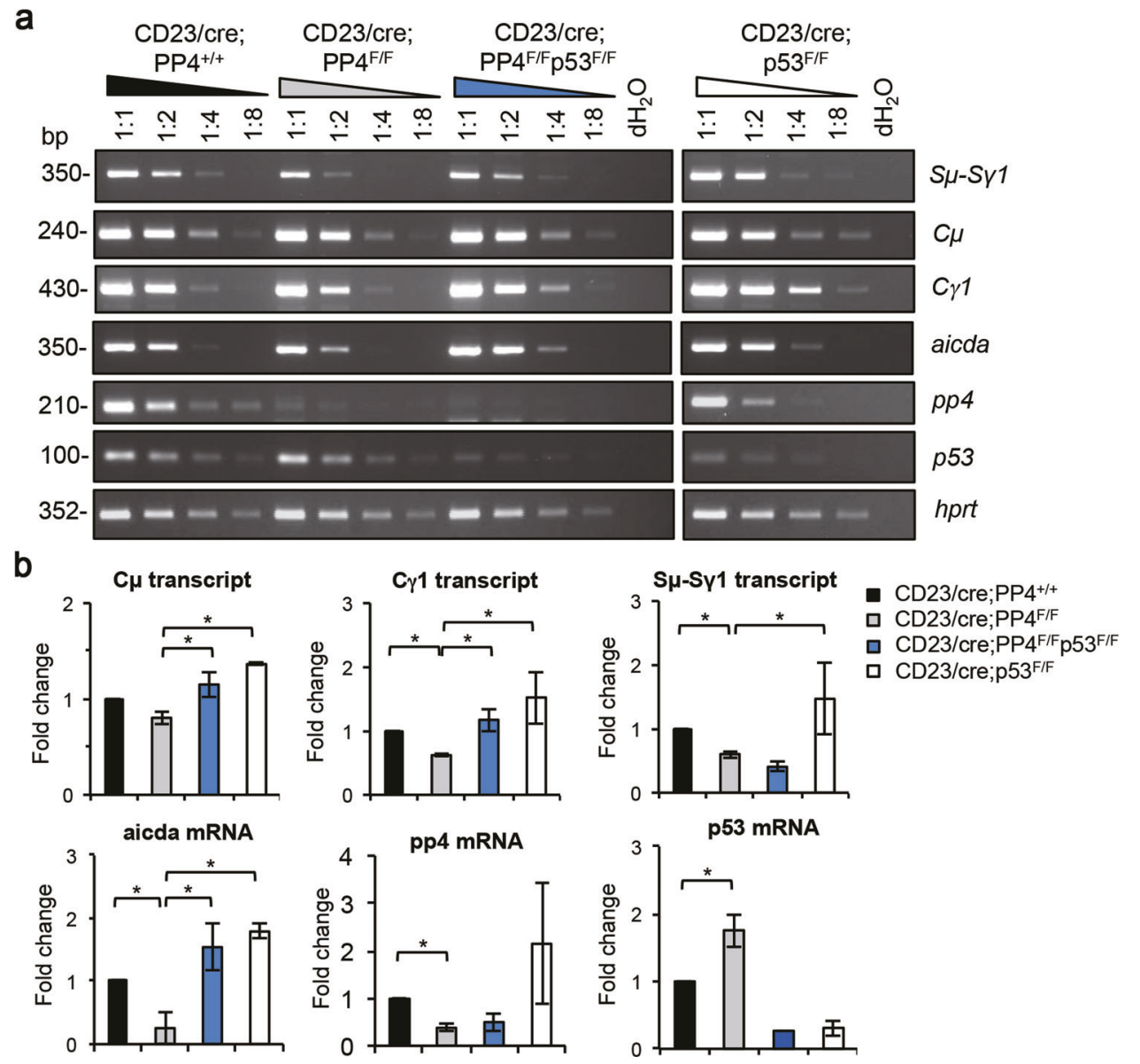

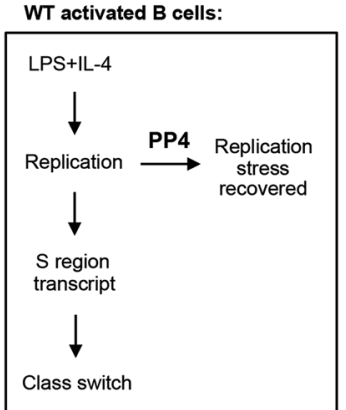

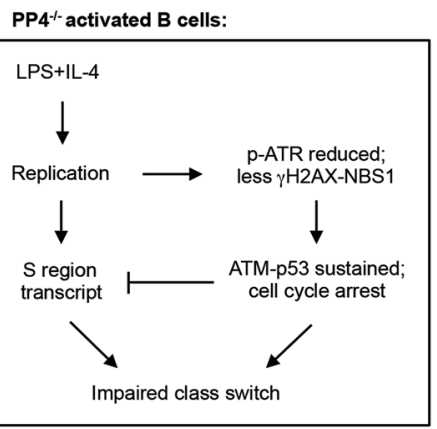

Fig. 7 Schematic illustration of proposed roles for PP4 in B cell proliferation and Ig class switching. (Left) In WT activated B cells, LPS + IL-4 stimulation results in cell proliferation requiring DNA replication. In the presence of PP4, replication stress is prevented, S region transcripts are produced, CSR occurs with normal efficiency, and Ig class switching is normal. (Right) In activated PP4-deficient B cells, ATR activation is decreased and reduces the retention of $\gamma \mathrm{H} 2 \mathrm{AX}-\mathrm{NBS} 1$ complexes on the DNA DSB sites needed for DNA replication and CSR. A sustained DNA damage response is triggered via the ATM-p53 axis that results in cell cycle arrest, promoting cell viability. On the other hand, p53 exerts a suppressive effect on the production of germline acceptor $\mathrm{S}$ region transcripts

(data not shown) because CSR takes place late during GC formation. However, we found that deletion of both PP4 and $\mathrm{p} 53$ by $\mathrm{AID} / \mathrm{cre}$ in vivo partially restored the frequency of $\operatorname{IgG} 1^{+}$B cells in mutant mice immunized with TNR-KLH. Interestingly, most of the $\mathrm{IgG1}^{+} \mathrm{B}$ cells isolated from these double mutant mice lack CD138 expression, suggesting that their differentiation occurs in a GC-independent manner in vivo.

It is notable that LPS + IL-4 stimulation induced the ATM-p53 pathway modestly in WT B cells but dramatically in PP4-deficient B cells. Genetic ablation of both PP4 and p53 by CD23/cre did not rescue the Ig class switching defect apparent in B cells lacking PP4 alone, suggesting that PP4 deficiency impairs DNA replication via a p53-independent mechanism. Nevertheless, double deficiency of PP4 and p53 in B cells mediated by CD23/ cre significantly promoted the production of germline acceptor $\mathrm{S}$ region transcripts, and the level of these transcripts is an important determinant of class switching [59]. These results suggest that p53 acts as a gatekeeper controlling the level of germline acceptor $\mathrm{S}$ region transcripts. Taken together, our study indicates that p53 plays a dual role in CSR in PP4-deficient B cells. On one hand, p53 sustains the viability of PP4-deficient B cells through p21-mediated cell cycle arrest, which is beneficial for the repair of DSBs induced during DNA replication. On the other hand, p53 stabilization in B cells exerts a 
suppressive effect on the production of germline acceptor $S$ region transcripts.

H2AX and NBS1 act synergistically in the HR pathway of DNA repair $[12,13]$. The accumulation of NBS1- $\gamma$ H2AX complexes on DNA damage sites is essential for the repair and rejoining of DSBs, a process that is coordinated with the induction of cell cycle arrest [60]. NBS1 is phosphorylated at S343 by ATM in response to radiation, an event that mediates an $\mathrm{S}$ phase checkpoint [55-57]. Mutation of NBS1 S343 disturbs this $S$ phase arrest and reduces DNA repair by HR [61]. We find that, in B cells where PP4 deficiency is mediated by CD23/cre, $p$-NBS1 S343 is slightly accumulated in the cytosolic fraction of cells at $24 \mathrm{~h}$ post-stimulation by LPS + IL-4, suggesting that the $S$ phase checkpoint imposed by ATM-NBS1 is activated in PP4-deficient B cells. In addition, the cytosolic retention of $p$-NBS1 S343 is associated with a dramatic reduction of nuclear NBS1 in PP4-deficient B cells. PP4 has been shown to dephosphorylate RPA2, which is necessary for efficient HR-mediated DNA repair [36]. Abolition of RPA2 phosphorylation impedes the loading of the essential repair factor RAD51 and extends the G2-M checkpoint. Interestingly, we show that loss of PP4 strongly reduces RPA1-intenstiy in resting and LPS + IL-4-stimualted B cells, suggesting that the RPA complex in the absence of PP4 is defective in the complex assembly. Whether the nuclear translocation of NBS1 is directly regulated by PP4, or is an indirect effect mediated by RPA disassembly, requires further investigation.

Our finding implies that PP4 deficiency in B cells affects the sequential recruitment of RPA and NBS1, leading to an impaired ATR signaling pathway, which is required for cell proliferation. Due to the key roles of NBS1 and $\gamma \mathrm{H} 2 \mathrm{AX}$ in CSR, the reduction in NBS1$\gamma \mathrm{H} 2 \mathrm{AX}$ complexes exerted by PP4 deficiency further decreases CSR efficiency. Our study therefore establishes that PP4 is a key component required for efficient recruitment of NBS1 and $\gamma \mathrm{H} 2 \mathrm{AX}$ during $\mathrm{B}$ cell proliferation and Ig class switching.

Acknowledgements We are grateful to Dr. Meinrad Busslinger (Research Institute of Molecular Pathology, Vienna Biocenter, Vienna, Austria) for kindly sharing CD23/cre and AID/cre mice. We would like to thank the Laboratory Animal Center of NHRI for animal care and the NHRI Core Instrument Center for confocal microscopy service and equipment. This work was financially supported by NHRI intramural funding and by the Ministry of Science and Technology (MOST) grants 103-2320-B-400-005 and 105-2320-B-400-008.

\section{Compliance with ethical standards}

Conflict of interest The authors declare that they have no conflict of interest.
Open Access This article is licensed under a Creative Commons Attribution 4.0 International License, which permits use, sharing, adaptation, distribution and reproduction in any medium or format, as long as you give appropriate credit to the original author(s) and the source, provide a link to the Creative Commons license, and indicate if changes were made. The images or other third party material in this article are included in the article's Creative Commons license, unless indicated otherwise in a credit line to the material. If material is not included in the article's Creative Commons license and your intended use is not permitted by statutory regulation or exceeds the permitted use, you will need to obtain permission directly from the copyright holder. To view a copy of this license, visit http://creativecommons. org/licenses/by/4.0/.

\section{References}

1. Pavri R, Nussenzweig MC. AID targeting in antibody diversity. Adv Immunol. 2011;110:1-26.

2. Stavnezer J, Schrader CE. IgH chain class switch recombination: mechanism and regulation. J Immunol. 2014;193:5370-8.

3. Hwang JK, Alt FW, Yeap LS. Related mechanisms of antibody somatic hypermutation and class switch recombination. Microbiol Spectr. 2015;3:MDNA3-0037-2014.

4. Rogakou EP, Pilch DR, Orr AH, Ivanova VS, Bonner WM. DNA double-stranded breaks induce histone $\mathrm{H} 2 \mathrm{AX}$ phosphorylation on serine 139. J Biol Chem. 1998;273:5858-68.

5. Kobayashi J, Tauchi H, Sakamoto S, Nakamura A, Morishima K, Matsuura S, et al. NBS1 localizes to gamma-H2AX foci through interaction with the FHA/BRCT domain. Curr Biol. 2002;12: 1846-51.

6. Falck J, Coates J, Jackson SP. Conserved modes of recruitment of ATM, ATR and DNA-PKcs to sites of DNA damage. Nature. 2005;434:605-11.

7. Stiff T, Reis C, Alderton GK, Woodbine L, O’Driscoll M, Jeggo PA. Nbs1 is required for ATR-dependent phosphorylation events. EMBO J. 2005;24:199-208.

8. Carson CT, Orazio NI, Lee DV, Suh J, Bekker-Jensen S, Araujo FD, et al. Mislocalization of the MRN complex prevents ATR signaling during adenovirus infection. EMBO J. 2009;28:652-62.

9. Zou L, Elledge SJ. Sensing DNA damage through ATRIP recognition of RPA-ssDNA complexes. Science. 2003;300: 1542-8.

10. Liu S, Opiyo SO, Manthey K, Glanzer JG, Ashley AK, Amerin C, et al. Distinct roles for DNA-PK, ATM and ATR in RPA phosphorylation and checkpoint activation in response to replication stress. Nucleic Acids Res. 2012;40:10780-94.

11. Hufnagl A, Herr L, Friedrich T, Durante M, Taucher-Scholz G, Scholz M. The link between cell-cycle dependent radiosensitivity and repair pathways: a model based on the local, sister-chromatid conformation dependent switch between NHEJ and HR. DNA Repair. 2015;27:28-39.

12. Furuta $\mathrm{T}$, Takemura $\mathrm{H}$, Liao ZY, Aune GJ, Redon C, Sedelnikova OA, et al. Phosphorylation of histone H2AX and activation of Mre11, Rad50, and Nbs1 in response to replicationdependent DNA double-strand breaks induced by mammalian DNA topoisomerase I cleavage complexes. J Biol Chem. 2003;278:20303-12.

13. Tauchi H, Kobayashi J, Morishima K, van Gent DC, Shiraishi T, Verkaik NS, et al. Nbs1 is essential for DNA repair by homologous recombination in higher vertebrate cells. Nature. 2002;420: 93-8.

14. Celeste A, Petersen S, Romanienko PJ, Fernandez-Capetillo O, Chen HT, Sedelnikova OA, et al. Genomic instability in mice lacking histone H2AX. Science. 2002;296:922-7. 
15. Bassing $\mathrm{CH}$, Chua KF, Sekiguchi J, Suh H, Whitlow SR, Fleming $\mathrm{JC}$, et al. Increased ionizing radiation sensitivity and genomic instability in the absence of histone H2AX. Proc Natl Acad Sci USA. 2002;99:8173-8.

16. Tauchi H, Matsuura S, Kobayashi J, Sakamoto S, Komatsu K. Nijmegen breakage syndrome gene, NBS1, and molecular links to factors for genome stability. Oncogene. 2002;21:8967-80.

17. Petersen S, Casellas R, Reina-San-Martin B, Chen HT, Difilippantonio MJ, Wilson PC, et al. AID is required to initiate Nbs1/ gamma-H2AX focus formation and mutations at sites of class switching. Nature. 2001;414:660-5.

18. Reina-San-Martin B, Difilippantonio S, Hanitsch L, Masilamani RF, Nussenzweig A, Nussenzweig MC. H2AX is required for recombination between immunoglobulin switch regions but not for intraswitch region recombination or somatic hypermutation. J Exp Med. 2003;197:1767-78.

19. Reina-San-Martin B, Nussenzweig MC, Nussenzweig A, Difilippantonio S. Genomic instability, endoreduplication, and diminished Ig class-switch recombination in B cells lacking Nbs1. Proc Natl Acad Sci USA. 2005;102:1590-5.

20. Matthews AJ, Zheng S, Dimenna LJ, Chaudhuri J. Regulation of immunoglobulin class-switch recombination: choreography of noncoding transcription, targeted DNA deamination, and longrange DNA repair. Adv Immunol. 2014;122:1-57.

21. Toyo-oka K, Mori D, Yano Y, Shiota M, Iwao H, Goto H, et al. Protein phosphatase 4 catalytic subunit regulates Cdk1 activity and microtubule organization via NDEL1 dephosphorylation. J Cell Biol. 2008;180:1133-47.

22. Helps NR, Brewis ND, Lineruth K, Davis T, Kaiser K, Cohen PT. Protein phosphatase 4 is an essential enzyme required for organisation of microtubules at centrosomes in Drosophila embryos. J Cell Sci. 1998;111:1331-40.

23. Zhang X, Ozawa Y, Lee H, Wen YD, Tan TH, Wadzinski BE, et al. Histone deacetylase 3 (HDAC3) activity is regulated by interaction with protein serine/threonine phosphatase 4 . Genes Dev. 2005;19:827-39.

24. Shui JW, Hu MC, Tan TH. Conditional knockout mice reveal an essential role of protein phosphatase 4 in thymocyte development and pre-T-cell receptor signaling. Mol Cell Biol. 2007;27:79-91.

25. Mihindukulasuriya KA, Zhou G, Qin J, Tan TH. Protein phosphatase 4 interacts with and down-regulates insulin receptor substrate 4 following tumor necrosis factor-alpha stimulation. J Biol Chem. 2004;279:46588-94.

26. Hu MC, Tang-Oxley Q, Qiu WR, Wang YP, Mihindukulasuriya KA, Afshar R, et al. Protein phosphatase $X$ interacts with c-Rel and stimulates c-Rel/nuclear factor kappaB activity. J Biol Chem. 1998;273:33561-5.

27. Yeh PY, Yeh KH, Chuang SE, Song YC, Cheng AL. Suppression of MEK/ERK signaling pathway enhances cisplatin-induced NFkappaB activation by protein phosphatase 4-mediated NF-kappaB p65 Thr dephosphorylation. J Biol Chem. 2004;279:26143-8.

28. Brechmann M, Mock T, Nickles D, Kiessling M, Weit N, Breuer $\mathrm{R}$, et al. A PP4 holoenzyme balances physiological and oncogenic nuclear factor-kappa B signaling in T lymphocytes. Immunity. 2012;37:697-708.

29. Lee J, Adelmant G, Marto JA, Lee DH. Dephosphorylation of DBC1 by Protein Phosphatase 4 Is Important for p53-Mediated Cellular Functions. Mol Cells. 2015;38:697-704.

30. Liu J, Xu L, Zhong J, Liao J, Li J, Xu X. Protein phosphatase PP4 is involved in NHEJ-mediated repair of DNA double-strand breaks. Cell Cycle. 2012;11:14.

31. Lee DH, Goodarzi AA, Adelmant GO, Pan Y, Jeggo PA, Marto JA, et al. Phosphoproteomic analysis reveals that PP4 dephosphorylates KAP-1 impacting the DNA damage response. EMBO J. 2012;31:2403-15.
32. Shaltiel IA, Aprelia M, Saurin AT, Chowdhury D, Kops GJ, Voest $\mathrm{EE}$, et al. Distinct phosphatases antagonize the p53 response in different phases of the cell cycle. Proc Natl Acad Sci USA. 2014;111:7313-8.

33. Keogh MC, Kim JA, Downey M, Fillingham J, Chowdhury D, Harrison JC, et al. A phosphatase complex that dephosphorylates gammaH2AX regulates DNA damage checkpoint recovery. Nature. 2006;439:497-501.

34. Chowdhury D, Xu X, Zhong X, Ahmed F, Zhong J, Liao J, et al. A PP4-phosphatase complex dephosphorylates gamma-H2AX generated during DNA replication. Mol Cell. 2008;31:33-46.

35. Nakada S, Chen GI, Gingras AC, Durocher D. PP4 is a gamma H2AX phosphatase required for recovery from the DNA damage checkpoint. EMBO Rep. 2008;9:1019-26.

36. Lee DH, Pan Y, Kanner S, Sung P, Borowiec JA, Chowdhury D. A PP4 phosphatase complex dephosphorylates RPA2 to facilitate DNA repair via homologous recombination. Nat Struct Mol Biol. 2010;17:365-72.

37. Lipinszki Z, Lefevre S, Savoian MS, Singleton MR, Glover DM, Przewloka MR. Centromeric binding and activity of Protein Phosphatase 4. Nat Commun. 2015;6:5894.

38. Wu G, Ma Z, Qian J, Liu B. PP4R1 accelerates cell growth and proliferation in HepG2 hepatocellular carcinoma. Onco Targets Ther. 2015;8:2067-74.

39. Huang X, Liu J, Shen T, Meng X, Dou L, Lin Y, et al. Protein phosphatase 4 plays dual roles during cell proliferation. Cell Prolif. 2016;49:219-35.

40. Liao FH, Hsiao WY, Lin YC, Chan YC, Huang CY. T cell proliferation and adaptive immune responses are critically regulated by protein phosphatase 4. Cell Cycle. 2016;15:1073-83.

41. Su YW, Chen YP, Chen MY, Reth M, Tan TH. The serine/ threonine phosphatase PP4 is required for pro-B cell development through its promotion of immunoglobulin VDJ recombination. PLoS One. 2013;8:e68804.

42. Chen MY, Chen YP, Wu MS, Yu GY, Lin WJ, Tan TH, et al. PP4 is essential for germinal center formation and class switch recombination in mice. PLoS One. 2014;9:e107505.

43. Kwon K, Hutter C, Sun Q, Bilic I, Cobaleda C, Malin S, et al. Instructive role of the transcription factor E2A in early B lymphopoiesis and germinal center B cell development. Immunity. 2008;28:751-62.

44. Marino S, Vooijs M, van Der Gulden H, Jonkers J, Berns A. Induction of medulloblastomas in p53-null mutant mice by somatic inactivation of $\mathrm{Rb}$ in the external granular layer cells of the cerebellum. Genes Dev. 2000;14:994-1004.

45. Mayr C, Bartel DP. Widespread shortening of 3'UTRs by alternative cleavage and polyadenylation activates oncogenes in cancer cells. Cell. 2009;138:673-84.

46. Muramatsu M, Kinoshita K, Fagarasan S, Yamada S, Shinkai Y, Honjo T. Class switch recombination and hypermutation require activation-induced cytidine deaminase (AID), a potential RNA editing enzyme. Cell. 2000;102:553-63.

47. Mendez J, Stillman B. Chromatin association of human origin recognition complex, cdc6, and minichromosome maintenance proteins during the cell cycle: assembly of prereplication complexes in late mitosis. Mol Cell Biol. 2000;20:8602-12.

48. Canman CE, Lim DS, Cimprich KA, Taya Y, Tamai K, Sakaguchi $\mathrm{K}$. et al. Activation of the ATM kinase by ionizing radiation and phosphorylation ofp53. Science. 1998;281:1677-9.

49. Banin S, Moyal L, Shieh S, Taya Y, Anderson CW, Chessa L, et al. Enhanced phosphorylation of p53 by ATM in response to DNA damage. Science. 1998;281:1674-7.

50. Tibbetts RS, Brumbaugh KM, Williams JM, Sarkaria JN, Cliby WA, Shieh SY, et al. A role for ATR in the DNA damage-induced phosphorylation of p53. Genes Dev. 1999;13:152-7. 
51. Hu MC, Shui JW, Mihindukulasuriya KA, Tan TH. Genomic structure of the mouse PP4 gene: a developmentally regulated protein phosphatase. Gene. 2001;278:89-99.

52. Liu S, Shiotani B, Lahiri M, Marechal A, Tse A, Leung CC, et al. ATR autophosphorylation as a molecular switch for checkpoint activation. Mol Cell. 2011;43:192-202.

53. Flynn RL, Zou L. ATR: a master conductor of cellular responses to DNA replication stress. Trends Biochem Sci. 2011;36:133-40.

54. Liu Q, Guntuku S, Cui XS, Matsuoka S, Cortez D, Tamai K, et al. Chk1 is an essential kinase that is regulated by Atr and required for the G(2)/M DNA damage checkpoint. Genes Dev. 2000;14: $1448-59$.

55. Lim DS, Kim ST, Xu B, Maser RS, Lin J, Petrini JH, et al. ATM phosphorylates p95/nbs 1 in an S-phase checkpoint pathway. Nature. 2000;404:613-7.

56. Zhao S, Weng YC, Yuan SS, Lin YT, Hsu HC, Lin SC, et al. Functional link between ataxia-telangiectasia and Nijmegen breakage syndrome gene products. Nature. 2000;405:473-7.

57. Wu X, Ranganathan V, Weisman DS, Heine WF, Ciccone DN, O'Neill TB, et al. ATM phosphorylation of Nijmegen breakage syndrome protein is required in a DNA damage response. Nature. 2000;405:477-82.

58. Olson E, Nievera CJ, Liu E, Lee AY, Chen L, Wu X. The Mre11 complex mediates the S-phase checkpoint through an interaction with replication protein A. Mol Cell Biol. 2007;27: 6053-67.

59. Rothman P, Lutzker S, Gorham B, Stewart V, Coffman R, Alt FW. Structure and expression of germline immunoglobulin gamma 3 heavy chain gene transcripts: implications for mitogen and lymphokine directed class-switching. Int Immunol. 1990;2: 621-7.

60. Kobayashi J, Antoccia A, Tauchi H, Matsuura S, Komatsu K. NBS1 and its functional role in the DNA damage response. DNA Repair. 2004;3:855-61.

61. Rink L, Slupianek A, Stoklosa T, Nieborowska-Skorska M, Urbanska K, Seferynska I, et al. Enhanced phosphorylation of Nbs1, a member of DNA repair/checkpoint complex Mre11RAD50-Nbs1, can be targeted to increase the efficacy of imatinib mesylate against BCR/ABL-positive leukemia cells. Blood. 2007;110:651-60. 